OPEN ACCESS

Approved by:

Frontiers in Microbiology Editorial

Office,

Frontiers Media SA, Switzerland

*Correspondence:

Frontiers Production Office production.office@frontiersin.org

Specialty section:

This article was submitted to Evolutionary and Genomic

Microbiology,

a section of the journal

Frontiers in Microbiology

Received: 18 January 2019 Accepted: 18 January 2019

Published: 23 January 2019

Citation: Frontiers Production Office (2019) Erratum: Corrigendum: Revisiting the Taxonomy of the Genus Arcobacter:

Getting Order From the Caos.

Front. Microbiol. 10:121.

doi: 10.3389/fmicb.2019.00121

\section{Erratum: Corrigendum: Revisiting the Taxonomy of the Genus Arcobacter: Getting Order From the Caos}

\author{
Frontiers Production Office* \\ Frontiers Production Office, Frontiers Media SA, Lausanne, Switzerland
}

Keywords: Arcobacter, Aliarcobacter gen. nov., Pseudoarcobacter gen. nov., Haloarcobacter gen. nov., Malacobacter gen. nov., Poseidonibacter gen. nov., taxonomic criteria

\section{An Erratum on}

Corrigendum: Revisiting the Taxonomy of the Genus Arcobacter: Getting Order From the Caos by Pérez-Cataluña, A., Salas-Massó, N., Diéguez, A. L., Balboa, S., Lema, A., Romalde, J. L., et al. (2018). Front. Microbiol. 9:3123. doi: 10.3389/fmicb.2018.03123

To enable validation of the names of some of the newly proposed taxa described in this article, the original article should not have been updated following the publication of the corrigendum. The original version has now been reinstated.

Copyright (C) 2019 Frontiers Production Office. This is an open-access article distributed under the terms of the Creative Commons Attribution License (CC BY). The use, distribution or reproduction in other forums is permitted, provided the original author(s) and the copyright owner(s) are credited and that the original publication in this journal is cited, in accordance with accepted academic practice. No use, distribution or reproduction is permitted which does not comply with these terms. 